\title{
Teachers' Perspectives on the Role of L1 in Jordanian EFL Classes
}

\author{
Muath Algazo \\ Education Studies/Applied Linguistics, University of Western Ontario (UWO) \\ London, Ontario, Canada \\ E-mail: algazo@yahoo.com
}

Received: Nov. 30, 2021 Accepted: Jan. 19, 2022 Published: Jan. 24, 2022

doi:10.5296/elr.v8i1.19378ＵRL: https://doi.org/10.5296/elr.v8i1.19378

\begin{abstract}
This qualitative study explored English as a foreign language (EFL) teachers' perspectives on first language (L1) use in the second language (L2) classroom. The study focused on Jordanian public secondary school EFL teachers and drew on Macaro's (2001) three codeswitching positions - optimal (i.e., L1 use can enhance L2 learning), maximal (i.e., L1 use should be minimized in L2 learning), and virtual (i.e., L1 should never be used in L2 learning). Data were collected through a classroom observation and two rounds of interviews, one pre- and one post-observation. The findings suggested that teachers' views on L1 use varied depending on two main factors: 1) students' L2 proficiency, and 2) type of lesson. In terms of Macaro's (2001) framework, teachers held an optimal view toward L1 use with low-proficiency students, yet a maximal view with higher-proficiency students. Similarly, teachers held an optimal position toward L1 use in grammar classes, yet a maximal position in reading classes and a virtual position in listening and speaking classes. The findings of this study are unlike Macaro's (2001) results, which found that teachers hold a static position toward L1 use regardless of the proficiency of learners or lesson type. Finally, the present study found that teachers were aware of L1 overuse ramifications. The findings of this research may help L2 scholars, policy makers, and teacher-practitioners to understand the role of the L1 in the L2 classroom, particularly in the context of Jordan and similar EFL contexts.
\end{abstract}

Keywords: EFL teachers, L1 use, L2 classroom 


\section{Introduction}

The role of learners' first language (L1) in the second language (L2) classroom is a source of long-standing controversy in the fields of L2 and foreign language (FL) education. While one perspective holds that the L2 should be taught without intervention of learners' L1, another holds that learners' L1 can be used to advance L2 learning. In 2001, academic exchanges on the subject between Vivian Cook and Miles Turnbull opened the doors for scholars to further investigate the role of L1 in the L2 classroom. Cook (2001) argued against banning L1 use in the L2 classroom, as it is based on the fallacy that children do not use another language when acquiring their L1. Moreover, learners' L1 and L2 are connected to each other in the learner's mind; they cannot be separated. Cook encouraged teachers to share their L1 with their students and to use it to enhance the L2 teaching and learning process. Turnbull (2001) criticized Cook's stance, arguing instead to minimize L1 exposure and use in L2 learning to avoid stunting learner's L2 development.

The academic exchanges between Cook and Turnbull indicate the complexity of the issue of L1 use in the L2 classroom. Although numerous studies on the issue (e.g., Algazo, 2020; Bateman, 2008; De la Campa \& Nassaji, 2009; Lo, 2015; Shin, Dixon, \& Choi, 2020; Yildiz $\&$ Yesilyurt, 2017) have been published in the last two decades, it remains controversial. One of the reasons for the controversy may be the shortage of research that explores teachers' views on L1 use in L2 classrooms, which have received scant attention in the literature (Shin, Dixon, \& Choi, 2020). Moreover, little research has considered EFL contexts where L1 use in the L2 classroom is already quite common, such as in public schools in Jordan. This paper continues the work of Algazo (2018), which examines EFL teachers' perspectives toward the role of L1 use in the L2 classroom in public secondary schools in Jordan.

\section{Literature Review}

\subsection{Views on L1 Use in L2 Classrooms}

Macaro (2001) distilled disagreements about L1 use in the L2 classroom and argued they stem from proponents and opponents holding one of three different theoretical positions:

1) Optimal, which considers L1 use to be valuable and beneficial for L2 learning since it can enhance certain aspects of L2 learning (e.g., increase student comprehension of a grammar point).

2) Maximal, which considers the L1 to have no place in the L2 classroom-except when, because of the imperfect teaching conditions of a typical educational environment, teachers may need to use the L1 as a teaching resource to overcome certain challenges (e.g., students' low proficiency, limited time). In these cases, L1 use is permissible, even necessary.

3) Virtual, which considers the L1 to have no place in the L2 classroom under any circumstances. This position holds that there are no benefits to using the L1 in L2 contexts and therefore the L1 should be fully excluded from the L2 classroom.

Macaro's (2001) three positions have been be applied in second language acquisition (SLA) 
literature that considers teachers' views toward the role of L1 in the L2 classroom. Hlas (2016) explored 96 middle and high school teachers' views toward L1 use in the L2 classroom where Spanish was the L2 and English is the L1 in USA. The study found that most participants held an optimal position (85\%); few held a maximal (12\%) or virtual position (3\%). Conversely, Köylü (2018) asked 155 EFL teachers in Turkey about L1 use in the L2 classroom and found that $15 \%$ of participants held an optimal position, while $85 \%$ of participants were somewhere between a virtual and maximal position. The views of participants in these studies and in the literature generally are not consistent and may depend on a variety of factors.

Macaro's (2001) framework is not used consistently across the literature, however, and in many cases must be inferred. Several studies (e.g., Ahmed, 2015; Al-Balawi, 2016; De La Campa \& Nassaji, 2009; Taşçı \& Aksu Ataç, 2020) have explored teachers' attitudes toward L1 use in the L2 classroom but did not clarify with which of Macaro's positions their participants aligned. For example, Al-Balawi (2016) investigated the attitudes of $50 \mathrm{EFL}$ teachers in secondary schools in Saudi Arabia and reported that most participants had a positive attitude toward L1 use in the L2 classroom. Although not explained explicitly, it can be inferred that teachers' "positive attitude" (p. 51) most likely reflected Macaro's (2001) optimal view. Moreover, Al-Balawi (2016) noted that the participants used a considerable amount of L1 in their L2 classes (up to 80\%), which also aligns with Macaros' definition of an optimal position.

Shabir (2017) similarly explored the attitudes of 23 EFL teachers and found that participants preferred to use the L2 as much as possible in their classrooms, using the L1 only in particular circumstances where there was no better way to assist the students. In this study, although the author did not use Macaro's (2001) framework, it can be inferred that the teachers held a maximal position toward the role of the L1 in the L2 classroom, in part because the author used conservative language such as "limited use of L1" (p. 45). The author also stated, "teachers tend to use more and more English [L2] in their classroom except in particular circumstances and needs where they find no other choice but use L1 to assist some students" (p. 50). This description of teachers' attitude likewise aligns with Macaros' definition of maximal position.

Identifying Macaro's (2001) virtual position in SLA literature is less complicated because this position rejects any L1 use in the L2 classroom at all. Notably, however, the virtual view is rarely reported in the FL context where teachers and learners usually share a common L1. Rather, some reports of FL teachers stated virtual position (i.e., they claim to reject L1 use) contradict reports of their actual maximal practices, where the L1 is used or allowed in certain situations. For example, Alrabah, Wu, Alotaibi and Aldaihani (2016) found that while EFL teachers $(n=60)$ in their study used their L1 in their L2 classes, they displayed a negative attitude toward the role of the L1 in the L2 classroom generally and supported the exclusion of the L1 from the L2 classroom. Similarly, one EFL teacher-participant in Copland and Neokleous (2011) was a strong supporter of the exclusive use of the L2 in the L2 classroom (i.e., virtual position), and yet allowed to their students to use their L1 as needed (i.e., maximal position). Teachers' decisions about whether to use the L1 or not in the L2 classroom is thus 
complex and based on many different factors, where one teacher may hold more than one position at a time. Macaro's framework, however, does not account for multiple positionalities.

\subsection{L1 Overuse Versus Judicious Use}

One of the issues complicating discussions about L1 use in the L2 classroom is the acceptable amount of L1 in the L2 classroom, or L1 "overuse" (Fernández, 2015) versus "judicious use" (Lo, 2015). Turnbull (2001), for example, proposed that teachers who use the L2 for less than $25 \%$ of class time may be relying too heavily on the L1 and depriving their students of valuable L2 input. Shapson, Durward and Kaufman (1978) considered an acceptable ratio of $75 \%$ of class time in the L2 and $25 \%$ in the L1. Macaro (2005) suggested that $10-15 \%$ of class time in the L1 is appropriate, but anything beyond this threshold may adversely affect L2 learning. Calman and Daniel (1998), meanwhile, claimed that school boards should demand $95 \%$ of class time to be in the $\mathrm{L} 2$.

Recommendations aside, studies that have observed the amount of actual L1 use in L2 classrooms have reported significant variation, potentially due to the different contexts in which the studies were conducted. For example, Taşçı and Aksu Ataç (2020) conducted a study of EFL teachers in a public primary school of Turkey and found that participants all used comparable amounts of L1 in their classes, ranging from $21 \%$ to $30 \%$ of all classroom instruction time. In contrast, Chavez (2016) found that the amount of L1 (English) use by their study's participants (three German teachers in the USA) varied between $8.5 \%$ to up to $52 \%$ of class time. Izquierdo, Martínez, Pulido and Zúñiga (2016) found less disparity than Chavez in their study of L1 (Spanish) use among EFL teachers in secondary schools in Mexico, who used the L1 from 27\% to $69 \%$ of class time. Ahmed (2015) similarly reported that their participants (100 EFL teachers at secondary schools in Sudan) used the L1 between $20 \%$ to up to $80 \%$ of class time. More moderate variation was reported by Riordan (2015), whose analysis of German teachers' classroom recordings in Ireland found that L2 usage was only $43 \%$ of class time; yet, the same teachers' reported using the L2 $58 \%$ of the time via questionnaire.

The vast differences in the abovementioned studies suggest that there are many factors behind teachers' use of L1 in the L2 classroom. Potential factors identified in the literature include teaching experience (De la Campa \& Nessaji, 2009), type of lesson (Paker \& Karaağaç, 2015), and students' proficiency level (Taşçı \& Aksu Ataç, 2020). De la Campa and Nessaji (2009) noted that teaching experience influenced the amount of L1 use, where experienced L2 teachers used slightly fewer L1 words than novices. Bateman (2008) reported that the subject matter influences the amount of L1 use, where the study's participants felt that grammar and culture lessons demanded more L1 use than other subjects. Taşçı and Aksu Ataç (2020) found that students' low proficiency in the L2 prompted teachers to use more L1 in their classes.

All in all, the abovementioned studies reinforce that L2 teachers vary a lot in their L1 usage and that sometimes their reported and actual usage differ. Still, a common understanding across the studies is that unnecessary or excessive L1 use that hampers L2 development can be considered L1 overuse, while purposeful L1 use that aligns with L2 learning objectives 


\section{Macrothink}

can be considered judicious or selective use (Fernández, 2015; Lo, 2015; Macaro, 2005; Turnbull, 2001).

\subsection{Ramifications of L1 Overuse}

There are many "dangers" associated with L1 overuse (Bruen \& Kelly, 2017). The primary "danger" is L1 overuse in the L2 classroom may negatively influence the L2 learning process by depriving students of L2 input (Turnbull, 2001). Studies (Atkinson, 1987; Fernández, 2015; Rolin-Ianziti \& Varshney, 2008) have examined the ramifications of L1 overuse in the L2 classroom. Atkinson (1987), for example, argued that L1 overuse can cause students to become dependent on their L1 and as a result not reach a full understanding of aspects of the target language without translation. More specifically, Atkinson (1987) claimed that L1 overuse can lead to a poor understanding of equivalences and pragmatic features due to inaccurate translation; inadvertent over reliance on their L1 as a matter of course, despite their ability to use the L2; and failure to realize the importance of exclusively using the target language in some activities.

Rolin-Ianziti and Varshney (2008) also investigated the issue of excessive L1 use in L2 classrooms from the perspective of beginner French learners in an Australia. The research found that students felt that L1 usage posed some concerns regarding overuse, among them that it minimized students' opportunities for exposure to the target language and increased their L1 dependence. Fernández' (2015) study in Russia on FL likewise concluded that excessive L1 use greatly hampered learning outcomes.

Notably, research on the issue of dangers associated to the excessive use of the L1 in the context of L2 teaching and learning is very little. The literature absolutely needs more research on this issue to enrich it. The lack of studies on this issue might be due to the lack of clarity between the concept of "L1 overuse" (Fernández, 2015) and "judicious L1 use" (Lo, 2015).

\section{Methodology}

\subsection{Setting and Participants}

The participants in this study were six EFL teachers from four public secondary schools (Schools A, B, C, and D) in an Educational District in the northern part of Jordan. All participants were Jordanian with Arabic as their L1 and have been chosen randomly. Table 1 summarizes the teacher-participants' demographic information. All names in the table are pseudonyms. 
Table 1. Demographic information of teacher-participants

\begin{tabular}{lllll}
\hline Name & Gender & School & Experience (years) & Academic Qualifications \\
\hline Malek & Male & A & 22 & MA English Methodology \\
Muna & Female & A & 23 & BA English language \& Literature \\
Sumia & Female & B & 15 & Higher Diploma in technology and communication \\
Zeina & Female & B & 6 & BA English language and literature \\
Ahmad & Male & C & 14 & BA English language \& literature \\
& & & & Higher Diploma in English Methodology \\
Hala & Female & D & 20 & BA English language and literature \\
& & & & Higher Diploma in technology and communication
\end{tabular}

All participants had at least a university degree in English language and literature, a program that is offered at most Jordanian universities. Graduates of this program are qualified to work as English language teachers at primary and secondary schools in Jordan and other Arab countries. Some participants had further qualifications, such as diplomas or master's degrees. Their teaching experience of teachers ranged from six to twenty-three years. Of the six teachers, Malek and Muna taught in the same school (School A); Sumia and Zeina taught at the same school (School B); and Ahmad and Hala were from different schools (Schools C and $\mathrm{D}$, respectively). The participants therefore represented a fairly diverse group of perspectives.

\subsection{Data Collection}

This qualitative study employed two methods of data collection: classroom observations and interviews. The author observed one 45-minute Grade 10 or 11 English class taught by each of the six teacher-participants. Each teacher participated in two semi-structured interviews, one pre- observation and one post-observation. The pre-observation interview's questions were modified based on the interview's questions of Al Sharaeai (2012). The post-observation interview questions were developed based on the researcher's notes taken during the classroom observation. The author conducted all interviews in English at the participants' respective schools.

\subsection{Data Analysis}

Pre- and post-observation interviews were audio-recorded and transcribed in full by the 
researcher. Transcripts were then coded for emergent themes in two stages as per Charmaz (2014): initial coding, during which the researcher closely focused on the data, looking for themes in segments and jotting down words that reflect the recorded actions; and focused coding, during which the researcher looked for the most significant themes. Salient direct quotes from the participants' interview responses were identified during the coding process and used to reinforce the reporting of the findings.

\section{Findings and Discussion}

\subsection{Teachers' Views Toward L1 Use}

Data analysis revealed that the study's teacher-participants held different positions toward the role of L1 in the L2 classroom (i.e., optimal, maximal, or virtual) depending on two main factors: 1) their students' proficiency level, and 2) the type of lesson they were teaching. This finding was unlike Macaro's (2001), where teachers were found to hold a static position, i.e., regardless of proficiency level or type of lesson or other factors. This difference may be attributed to the context of teaching, which is known to significantly impact teaching and learning practices in the classroom (Azkarai \& Oliver, 2018). Macaro's participants taught French as a foreign language in south England to 11-14-year-old students who had been studying French for one to three years. In contrast, the participants in this study were EFL secondary school teachers (i.e., grades 11 and 12) whose students were 16-18 years old and had been studying English for more than 10 years. This difference in educational context may have affected teachers' views (Kang, 2013) and the studies not wholly comparable.

Another potential factor that may account for differences between these and Macaro's (2001) findings is the participating teachers' experience. Macaro's six teacher-participants were student-teachers who had little actual teaching experience. The six teachers in the present study, meanwhile, were expert teachers whose experience ranged from six to 23 years, where half of the participants had more than 20 years of teaching experience. Teaching experience can play a significant role in shaping teachers' beliefs (Lewis, 1990), including toward the role of L1 in the L2 classroom and the appropriate amount to use depending on the context.

\section{1) Students' proficiency level}

Teacher-participants' view toward the role of L1 in the L2 classroom was profoundly affected by the students' proficiency level, where the low proficiency students needed more L1 usage than higher proficiency students. In Macaro's (2001) terms, the teacher-participants held an optimal position toward L1 use with low proficiency students and a maximal position with higher proficiency students. For example, Zeina stated: "Using Arabic in the English language classes depends sometimes on the students' level in English language." Hala similarly said, "if you are teaching secondary stage, it is rarely to use Arabic but if you are teaching the basics [elementary] stages, I think you will need to use Arabic sometimes." For low proficiency students, the L1 was a valuable resource for increasing their comprehension of the L2 input.

The teacher-participants also showed an awareness that their classrooms included students of different proficiency levels and using more L1 with low proficiency students helped to 
decrease the proficiency gap between students in their L2 classroom. This was clear in Muna's view when she said, "We always have, in our classes, good students, weak students and excellent students. You have to deal with each of them separately from his colleagues." Zeina shared the same idea: in her classroom observation, she gave her students the Arabic meanings of some English words, which she justified in the post-observation interview:

[The Arabic meanings were given] because not all the students can understand the meaning of these words in English. Some can understand them in English without a need to use Arabic while the other [low-level proficiency students] cannot understand them in English only and they need Arabic to help them to understand better.

Muna and Zeina both pointed to the benefit that using the L1 enabled them to deal with low proficiency students by increasing those students' comprehension of L2 lessons to a level equal to that of their higher proficiency classmates, without a significant addition of time or effort.

A possible explanation for teachers' optimal view on L1 use based on students' proficiency is that majority of students in public schools of Jordan have low-level English proficiency (Dweik \& Abu Al Hommos, 2007). Reasons include English not usually being a part of students' lives outside of the classroom (Swaie, 2019) and the limited time assigned for learning EFL in Jordanian public schools which is four to six 45-minute classes weekly (Algazo, 2020).

Teachers' awareness about the potential for L1 use to enhance the L2 learning of low proficiency students may stem from their teaching experience. All of the teacher-participants in this study had moderate to considerable experience teaching English in the public-school context (their experience varied from six to twenty-three years). Teachers-participants may have learned, based on their teaching experience, over time that there are various benefits to the judicious use of the L1, such as easing communication between teachers and low proficiency students to create a more relaxed teaching and learning atmosphere (Bruen \& Kelly, 2017).

\section{2) Type of lesson:}

Interview data revealed that the type of lesson also influenced the teacher-participants' views on L1 use in the L2 classroom. All of them held a virtual position toward L1 use in listening and speaking classes, a maximal position in reading classes, and an optimal position overall. Zeina, for example, stated: "Reading lessons need less Arabic [L1] while grammar lessons need more Arabic. Different types of lessons need different amount of Arabic." Moreover, when the researcher asked Sumia whether she uses Arabic in her English classes, she said "Yes, it depends to what I am teaching in the class, it depends to the skill I am teaching." In this study, the type of lesson is a main factor that determines the views of participants toward the role of $\mathrm{L} 1 \mathrm{use}$.

\section{Grammar lessons}

In Sumia's classroom observation, she led an English grammar-focused lesson in which she 
used a considerable amount of Arabic. In the post-observation interview, Sumia justified this usage, "From my experience in teaching English language for 15 years, I find that it [L1 use] is an effective way in teaching grammar". She later added, "I have tried to use English only in grammar lessons, but I found that it is not effective at all". Similarly, Ahmad used a considerable amount of L1 in his grammar class, which he later justified: "I use Arabic to enable students [to] understand grammar. Grammar lessons are better explained in Arabic." He said he aimed for an appropriate amount of L1 use in his grammar lessons, as much as $50 \%$ of class time, yet in his reading classes L1 he tried not to use more than $20 \%$.

Teacher-participants' higher L1 use in grammar lessons may be accounted for by the nature of grammar lessons (i.e., complex topic). Grammar lessons require the teachers to explain sometimes complex grammar rules, offer clarifying examples and details, and provide comparisons between the L1 and L2 in which teachers may resort to L1 use as an effective tool to overcome these challenges. This is in line with the many studies (e.g., Bruen \& Kelly, 2017; Cook, 2001; Macaro, 2005) noted that L2 teachers usually tend to use more L1 amount in L2 grammar classes.

\section{$\underline{\text { Reading lessons }}$}

Consistently, the teacher-participants were conservative toward L1 use in English reading classes, where they tended to hold a maximal position. Besides Ahmad's suggestion that the amount of L1 use in reading classes should not exceed $20 \%$, he also said "I use it sometimes in reading lessons to give the meanings of words." Similarly, Zeina pointed out, "Reading lessons need some Arabic but not the same amount as in grammar." Malek also gave Arabic meanings for some English vocabulary, saying in his interview, "You know that it is a new unit, and they are new vocabularies, so I wanted to make sure that they understand the meanings of these words." Other teacher-participants who gave reading lessons during their classroom observation-Muna, Hala, and Zeina - also limited their L1 use, reserving it for translations of some English vocabulary items into Arabic, which they justified as an effective way to make sure that all their students comprehended the meaning of new words.

To summarize, although teachers generally tried to avoid L1 use as much as possible in reading lessons, they resorted to L1 use as a way to efficiently introduce new vocabulary in a way that they felt all students would comprehend. Explaining the meaning of new vocabulary items in the L2 may have required a lot of time, with no guarantee that all students would understand the meaning (Yildiz \& Yesilyurt, 2017).

In contrast, the teacher-participants generally maintained that listening and speaking lessons did not need any L1 intervention-i.e., they held a virtual position toward L1 use in those classes. For example, when the researcher asked Hala if she needs Arabic in English speaking and listening classes, she said, "No, speaking and listening lessons should be taught in English." Ahmad also pointed out, "I think teachers should use only English in listening and speaking classes." Zeina claimed, "Speaking lessons do not need Arabic in which students must ask and answer questions in English only." Unfortunately, none of the teacher-participants' speaking or listening classes were observed, and so it is impossible to know to what extent their practices matched their views on this point. 
Teacher-participants may have needed to use the L1 less in listening and speaking lessons because, unlike in reading and grammar lessons, they tend not to require the teacher to be the main source of information. Specifically, in these lessons teacher do not generally need to relay large quantities of information; instead, they primarily manage the class activities. Avoiding L1 use in listening and speaking classes have been noted in many studies (e.g., Bateman, 2008; Paker \& Karaağaç, 2015) in the literature. Teachers believe that avoidance of L1 use in listening and speaking classes enable students to improve listening comprehension and speaking ability (Bateman, 2008).

\subsection{Negative Ramifications of L1 Overuse}

One of the aims of this study was to understand how teacher-participants perceived the concept of L1 overuse and its ramifications, whether real, perceived, or potential.

Based on interview data, teacher-participants were very aware to the concept of L1 overuse. Malek, for example, argued, "[using L1 in the L2 classroom] it is acceptable in some situations, but to overuse it or use it without any reason, this is definitely a very bad thing." Sumia likewise asserted, "teachers should use Arabic in correct times, I use Arabic when I only need it, but I do not overuse it to avoid negative effects". Teacher-participants' awareness of the concept L1 overuse may be attributed to their experience. Overreliance on the L1 has been related to teacher inexperience (De La Campa \& Nassaji, 2009) whereas all teachers in the present study had moderate to considerable experience teaching English in the public-school context, varying from six to twenty-three years.

Teacher-participants' awareness of L1 overuse may also be due to Jordan's teaching policies that discourage L1 use in L2 classrooms. For example, when the researcher asked Hala if she broke with policy guidelines when she used Arabic in her English class, she said, "Yes. If my supervisor comes to observe my class and finds me using Arabic in teaching English, this will be a negative point on my record." In addition, she stated, "In the English Teacher's Manual, teachers should not translate anything into Arabic unless as the final option." Hala and probably most Jordanian EFL teachers are aware of the teaching policies that restrict L1 use during L2 instruction particularly a strict monolingual policy acts to silence or reduce L1 use (McMillan \& Rivers, 2011).

\subsubsection{Limiting the L2 Development Process}

This study's teacher-participants suggested that L1 overuse could limit L2 development by minimizing students' exposure to the L2 and thus restricting their opportunities to practice it. Muna pointed out, "When we use Arabic most of the time, when we allow students to use Arabic ... this will limit their ability of using the English language." Ahmad shared the same view: "Using Arabic too much during the class does not help students to improve their English language." Hala similarly claimed, "It [L1 overuse] will make acquiring the language slow". Teacher-participants were clearly cognizant that L1 overuse can hinder the L2 learning process by depriving their students of L2 exposure. They also believe that L1 overuse deprives students of exposure to the L2 and to immerse in the target language experience and profoundly affects students' proficiency (Turnbull, 2001). Hence, the more 
the students rely on their L1 the more accuracy and fluency are affected (Fernández, 2015).

\subsubsection{Negative Affective Impact}

The teacher-participants in the present study found that L1 overuse reinforced students' shyness or lack of confidence when they use the L2 with their peers. Muna, for example, said, "If I won't use English language in the classroom the students won't care to use English like me. They always feel shy and afraid of using English and making mistakes". She later added, "Therefore, we have to encourage them to talk and to write, to communicate in every possible way in English language during the English lesson." Malek expressed the same idea when the researcher asked him if he allows to his students to use Arabic in the English language class:

I don't want them to overuse Arabic because I told you it is a foreign language, and they should speak it. Sometimes, I feel that my students are shame of using English, so I encourage them to use English and to be risk takers in order to use the language [L2].

Malek thought that L1 overuse would affect his students' motivation to learn the L2, and so he encouraged them to use the L2 as much as possible in order to increase their confidence in their abilities.

Fear or shyness at the thought of publicly using the L2 is a deeper habit that requires longer-term practice to break. Thus, maximizing L2 use will increase the students' confidence over the long term, and allow them to use L2 freely, with less shyness or fear which may deprive students' academic and social engagement in class. The notion that L1 overuse can demotivate students was over the long term was introduced in MacDonald (1993). More recently, Turnbull (2001) claimed that maximizing the use of the L2 increases students' motivation to learn it because the learners discovered for themselves how knowledge of the L2 benefitted them.

\section{Conclusion}

This study investigated Jordanian EFL teachers' views of L1 use and found that it varied depending on students' proficiency level and the type of lesson. Using Macaro's (2001) framework, teachers held an optimal view toward L1 use with low proficiency students and a maximal view with higher proficiency students. With respect to the lesson type, teachers held an optimal position in grammar classes, a maximal position in reading classes, and a virtual position in listening and speaking classes. The findings of this study are unlike Macaro's (2001), as Macaro's data showed that teachers hold static position toward L1 use regardless of students' proficiency and the lesson's type. Furthermore, this study found that teacher-participants were aware of the potential negative ramifications of L1 overuse, including: 1) limiting L2 development by further minimizing students' already limited exposure to the L2; and 2) demotivating students over the long term by not helping them to overcome shyness or fear of using the L2 in public.

The findings were based on limited data (one classroom observation per teacher; no listening or speaking classes) from a limited number of participants and are thus not widely generalizable. Nonetheless, this study may help to bridge the gap between research and 
practice by contributing to a deeper understanding of the factors involved in L2 teaching in foreign contexts.

\section{References}

Ahmed, S. H. A. (2015). Exploring Sudanese secondary schools teachers' attitudes towards the use of Arabic Language in EFL classroom. Journal of Humanities and Social Science, $20(6), 72-77$.

Al Sharaeai, W. (2012). Students' perspectives on the use of L1 in English classrooms. MA thesis, Iowa State University. Retrieved from https://search.proquest.com/docview/1269526199?pq-origsite=primo

Al-Balawi, F. S. (2016). The attitudes of Saudi EFL teachers about using their mother tongue in EFL classrooms. International Journal of Education and Social Science, 3(7), 51-61.

Algazo, M. (2018). The Role of First Language (L1) in the Second Language (L2) Classroom: The Case of Jordanian Public Schools. MA thesis, Carleton University. Retrieved from https://curve.carleton.ca/95957278-ace3-472f-9323-9dbc81831be0

Algazo, M., (2020). Functions of L1 Use in EFL Classes: Students' Observations. International Journal of Linguistics, 12(6), 140-149. https://doi.org/10.5296/ijl.v12i6.17859

Alrabah, S., Wu, S. H., Alotaibi, A. M., \& Aldaihani, H. A. (2016). English teachers' use of learners' L1 (Arabic) in college classrooms in Kuwait. English Language Teaching, 9(1), 1-11. https://doi.org/10.5539/elt.v9n1p1

Atkinson, D. (1987). The mother tongue in the classroom: A neglected resource? ELT Journal, 41(4), 241-247. https://doi.org/10.1093/elt/41.4.241

Azkarai, A., \& Oliver, R. (2018). Teaching EFL to young learners. In R. Oliver \& B. Nguyen (Eds.), Teaching young second language learners: Practices in different classroom contexts (pp. 89-108). Routledge. https://doi.org/10.4324/9781315149813-5

Bateman, B. E. (2008). Student teachers' attitudes and beliefs about using the target language in the classroom. Foreign Language Annals, 41(1), 11-28. https://doi.org/10.1111/j.1944-9720.2008.tb03277.x

Bruen, J., \& Kelly, N. (2017). Using a shared L1 to reduce cognitive overload and anxiety levels in the L2 classroom. The Language Learning Journal, 45(3), 368-381. https://doi.org/10.1080/09571736.2014.908405

Calman, R., \& Daniel, I. (1998). A board's eye view of core French: The North York Board of Education. In S. Lapkin (Ed.), French second language education in Canada: Empirical studies (pp. 281-323). Toronto: University of Toronto Press.

Charmaz, K. (2014). Constructing grounded theory (2nd ed.). Thousand Oaks, CA: SAGE.

Chavez, M. (2016). The first language in the foreign language classroom: teacher model and student language use-an exploratory study. Classroom Discourse, 7(2), 131-163. 
https://doi.org/10.1080/19463014.2016.1149499

Cook, V. (2001). Using the first language in the classroom. Canadian Modern Language Review, 57(3), 402-423. https://doi.org/10.3138/cmlr.57.3.402

Copland, F., \& Neokleous, G. (2011). L1 to teach L2: Complexities and contradictions. ELT Journal, 65(3), 270-280. https://doi.org/10.1093/elt/ccq047

De La Campa, J., \& Nassaji, H. (2009). The amount, purpose, and reasons for using L1 in L2 $\begin{array}{lllll}\text { classrooms. Foreign } \quad \text { Language } & \text { Annals, } & \text { 42(4), }\end{array}$ https://doi.org/10.1111/j.1944-9720.2009.01052.x

Dweik, B. S., \& Abu Al Hommos, M. D. (2007). The Effect of Arabic Proficiency on the English Writing of Bilingual-Jordanian Students. Online Submission.

Fernández, R. F. F. (2015). The effects of L1 overuse in L2 learning: Evidence from three case studies. International E-Journal of Advances in Education, 1(3), 183-192. https://doi.org/10.18768/ijaedu.53675

Hlas, A. C. (2016). Secondary teachers' language usage: Beliefs and practices. Hispania, 99(2), 305-319. https://doi.org/10.1353/hpn.2016.0060

Izquierdo, J., Martínez, V. G., Pulido, M. G. G., \& Zúñiga, S. P. A. (2016). First and target language use in public language education for young learners: Longitudinal evidence from Mexican secondary-school classrooms. System, 61(1), 20-30. https://doi.org/10.1016/j.system.2016.07.006

Kang, D. M. (2013). EFL teachers' language use for classroom discipline: A look at complex interplay of variables. System, 41(1), 149-163. https://doi.org/10.1016/j.system.2013.01.002

Köylü, Z. (2018). The use of L1 in the tertiary L2 classroom: Code-switching factors, functions, and attitudes in Turkey. Electronic Journal of Foreign Language Teaching, 15(2), 271-289.

Lewis, H. (1990). A question of values. San Francisco: Harper \& Row.

Lo, Y. Y. (2015). How much L1 is too much? Teachers' language use in response to students' abilities and classroom interaction in Content and Language Integrated Learning. International Journal of Bilingual Education and Bilingualism, 18(3), 270-288. https://doi.org/10.1080/13670050.2014.988112

Macaro, E. (2001). Analyzing student teachers' codeswitching in foreign language classrooms: Theories and decision making. The Modern Language Journal, 85(4), 531-548. https://doi.org/10.1111/0026-7902.00124

Macaro, E. (2005). Codeswitching in the L2 classroom: A communication and learning strategy. In Non-native language teachers (pp. 63-84). Springer, Boston, MA. https://doi.org/10.1007/0-387-24565-0_5

MacDonald, C. (1993). Using the target language. Cheltenham, UK: Mary Glasgow 
Publication.

McMillan, B. A., \& Rivers, D. J. (2011). The practice of policy: Teacher attitudes toward “English only". System, 39(2), 251-263. https://doi.org/10.1016/j.system.2011.04.011

Paker, T., \& Karaağaç, Ö. (2015). The use and functions of mother tongue in EFL classes. Procedia-Social and Behavioral Sciences, 199, 111-119. https://doi.org/10.1016/j.sbspro.2015.07.494

Riordan, E. (2015). The policy and practice of teacher target language use in post-primary foreign language classrooms in Ireland. European Journal of Language Policy, 7(2), 165-179. https://doi.org/10.3828/ejlp.2015.10

Rolin-Ianziti, J., \& Varshney, R. (2008). Students' views regarding the use of the first language: An exploratory study in a tertiary context maximizing target language use. Canadian Modern Language Review, 65(2), 249-273. https://doi.org/10.3138/cmlr.65.2.249

Shabir, M. (2017). Student-Teachers' Beliefs on the Use of L1 in EFL Classroom: A Global Perspective. English Language Teaching, 10(4), 45-52. https://doi.org/10.5539/elt.v10n4p45

Shapson, S., Durward, M., \& Kaufman, D. (1978). "Summary, Conclusions and Suggestions" Chapter from BC French Study: An Evaluation of Elementary French Programs in British Columbia. Burnaby: Faculty of Education, Simon Fraser University.

Shin, J. Y., Dixon, L. Q., \& Choi, Y. (2020). An updated review on use of L1 in foreign language classrooms. Journal of Multilingual and Multicultural Development, 41(5), 406-419. https://doi.org/10.1080/01434632.2019.1684928

Swaie, M. T. A. (2019). An Investigation of Jordanian English as a Foreign Language (EFL) Teachers' Perceptions of and Practices in Classroom Assessment. MA dissertation, Carleton University. Retrieved from https://curve.carleton.ca/e61926cb-de7e-44a0-956b-6fd4729a41b5

Taşçı, S., \& Aksu Ataç, B. (2020). L1 Use in L2 Teaching: The Amount, Functions, and Perception towards the Use of L1 in Turkish Primary School Context. International Online Journal of Education and Teaching, 7(2), 655-667.

Turnbull, M. (2001). There is a role for the L1 in second and foreign language teaching, but... Canadian Modern Language Review, 57(4), 531-540. https://doi.org/10.3138/cmlr.57.4.531

Yildiz, M., \& Yesilyurt, S. (2017). Use or Avoid? The Perceptions of Prospective English Teachers in Turkey about L1 Use in English Classes. English Language Teaching, 10(1), 84-96. https://doi.org/10.5539/elt.v10n1p84 


\section{Macrothink

\section{Copyright Disclaimer}

Copyright reserved by the author(s).

This article is an open-access article distributed under the terms and conditions of the Creative Commons Attribution license (http://creativecommons.org/licenses/by/4.0/). 